\title{
The Effect of Soil Pollution by Oil Derivatives on Harpalus rufipes Deg. (Coleoptera, Carabidae)
}

\author{
Janina Gospodarek ${ }^{1 *}$, Przemysław Petryszak ${ }^{2}$ \\ ${ }^{1}$ Department of Agricultural Environment Protection, University of Agriculture, Kraków, Poland \\ ${ }^{2}$ Unit of Biochemistry, Institute of Plant Biology and Biotechnology, Faculty of Biotechnology and Horticulture, \\ University of Agriculture, Kraków, Poland
}

Received: 24 August 2018

Accepted: 4 November 2018

\begin{abstract}
We investigated the subsequent effect of oil derivatives on life parameters of Harpalus rufipes Deg. (Coleoptera, Carabidae) and the accumulation of polycyclic aromatic hydrocarbons in its body. We also attempted to determine the influence of the presence of H. rufipes on the total content of oil derivatives in soil. The following objects were established: control - unpolluted soil; soil polluted with petrol; soil polluted with diesel fuel and soil polluted with used engine oil. Oil derivatives were used in a dose of $6000 \mathrm{mg}$ of fuel / $\mathrm{kg} \mathrm{d}$.m. of soil. In the laboratory, survival and body mass change of H. rufipes reared in soil contaminated with petroleum products, as well as their influence on the oil content in soil, was investigated. Harpalus rufipes Deg. reveals sensitivity to the presence in its vicinity of engine oil and diesel fuel, visible as decreased survival rate, whereas petrol does not affect the beetle condition. The analysed kinds of oil derivatives did not negatively affect beetle body mass gain. Soil experiments did not reveal any dependence between the presence of the animals and the efficiency of total hydrocarbon degradation. A tendency for accumulation was observed for anthracene and benzo $[a]$ pyrene in conditions of soil polluted with petrol, and benzo[b]fluoranthene in engine oil-polluted soil, which may indicate a significant contribution of H. rufipes in the natural biodegradation of oil derivatives.
\end{abstract}

Keywords: petroleum products; soil; life parameters; carabids; PAH accumulation

\section{Introduction}

Harpalus rufipes Deg. beetles belong to the dominants in the Carabidae groups in various habitats [1-7]. At the same time, they are regarded as easily adjusting to sites under strong anthropopressure [8]. Their role as predators and herbivores makes them an important link in the food chain [9]. They have been

*e-mail: rrjgospo@cyf-kr.edu.pl also analysed from the perspective of their use for biomonitoring for the assessment of biodiversity [10]. Increasing consumption of petrochemical compounds increases the risk of environmental hazard [11]. The effect of pollutants on their first contact organisms is still inadequately recognized. Research on the impact of oil derivatives - petrol, used engine oil and diesel fuel - applied to the soil at a dose of $6000 \mathrm{mg}$ of fuel / kg d.m. of soil on the occurrence of H. rufipes in the open ground revealed that the activity of these species representatives under conditions of soil polluted with oil derivatives depends on the type of pollutant and on the 
time that passed from the moment of the soil pollution. Petrol had the least negative effect (visible only for the first four months after pollution), whereas the negative effects of diesel and engine oil were observed even 14 months for the moment of pollution [12].

Terrestrial invertebrates, of which Carabidae are a very numerous group, play a crucial role in the matter of cycling, including the processes of organic compounds breakdown. The animals' influence on soil pollutant content may result mainly from the ability to accumulate toxic compounds in animal tissue, but also from the presence of metabolic pathways allowing for xenobiotic biotransformation [13-16]. The composition of hydrocarbons accumulated in invertebrate bodies depends on the species specificity $[17,18]$. There is no direct relationship between pollutant accumulation and their toxicity. Therefore, the use of invertebrates both in the processes of biological purification of contaminated soil and for the assessment of environment quality requires determining the degree of their sensitivity to particular types of pollution, both on the specimen and population level. Features such as survival or reproduction rate are regarded as most sensitive indicators of the degree of soil pollution with PAHs for earthworms, Collembola or Gastropods. Moreover, these animals reveal a higher sensitivity to the mentioned pollutants than plants [19-24]. The available literature lacks information about the influence of other terrestrial invertebrate groups on the content of organic pollutants in soil, or about the degree of their sensitivity to pollutants and the level of harmful components of oil derivatives accumulation, e.g. PAHs.

The presented research aimed at: a) investigating the subsequent (within one year after the instance of contamination) impact of oil-derivative pollutants in soil on life parameters of $H$. rufipes, such as survival rate, change in body mass and abilities to kill prey; b) determining the influence of $H$. rufipes presence on total content of oil derivatives in soil; c) assessing the effect of oil derivatives in soil on the level of polycyclic aromatic hydrocarbons accumulation in these animals' bodies.

\section{Material and Methods}

The investigations were conducted at the Experimental Station of the University of Agriculture in Mydlniki near Kraków. In autumn 2009 indigenous soil was placed in $1 \mathrm{~m}^{3}$ containers with maintained natural layers arrangement. The containers were then dug into the soil so that their upper area was on the same level with the surrounding soil. The soil in containers was left untouched for 8 months in order to allow it to restore its natural biological efficiency. Subsequently, in June 2010 the soil in containers was polluted with the following oil derivatives: petrol (BP Unleaded 95), diesel oil (BP Diesel Fuel) and used engine oil (PLATINUM Classic Semisynthetic
$10 \mathrm{~W}-40$, used for one year in a petrol engine) in the amounts equal to $6000 \mathrm{mg}$ of fuel $/ \mathrm{kg} \mathrm{d}$. m. of soil. Four objects were identified: 1) Control - unpolluted soil; 2) Soil with simulated petrol leak; 3) Soil with simulated diesel oil leak; and 4) Soil with simulated used engine oil leak. The whole experiment was conducted in 4 replications according to randomized block design. In June 2011 (i.e., 12 months after soil contamination with oil derivatives) Harpalus rufipes rearing was conducted on the soil taken from individual containers. The animals were obtained from the area close to the containers. The rearing was conducted for 4 weeks under constant conditions at $24^{\circ} \mathrm{C}$ in $1000 \mathrm{~mL}$ containers. 23 specimens of both genders were transferred to each container with $300 \mathrm{~g}$ of analysed soil. The containers were covered with gauze for better ventilation. Every week, 30 larvae of Tenebrio molitor were supplied as food. Constant soil moisture was maintained by its sprinkling with distilled water. Each week of rearing, the number of live specimens and their body mass were registered, as well as the number of Tenebrio molitor larvae killed by $H$. rufipes. The experiment was conducted in three replications.

\section{Analysis of PAH Content in the Animal Material}

In order to assess PAH content in the animal material, c.a. 1.2-1.8 g of animal tissue was homogenized in $10 \mathrm{~mL}$ of hexane with a supplement of $1 \mathrm{~mL}$ of 1-methylchrysene in $50 \mu \mathrm{g} / \mathrm{mL}$ concentrations. The hexane extract was obtained in 3 cycles of homogenization (1 min, $10000 \mathrm{rpm}$ ). After completion of each homogenization cycle the filtrate was decanted to a centrifugal glass tube and the remaining animal tissue was treated with another dose of the solvent. When homogenization was completed, the extracts were centrifuged (3000 rpm; $\left.4^{\circ} \mathrm{C}, 10 \mathrm{~min}\right)$ and then transferred quantitatively to Erlenmeyer flasks. The extraction thimbles were washed with hexane, which was added to previously decanted extracts. The extracts obtained in this way were then condensed until dry in a vacuum evaporator and afterward the remains were suspended in $1 \mathrm{~mL}$ of hexane.

The quantitative and qualitative analysis of individual PAHs present in the hexane extracts obtained from the animal material was conducted using a Shimadzu GC-17A ver.3 gas chromatograph equipped with Shimadzu QP-5000 mass spectrometer. Separations were conducted in SLB-5ms capillary column (Supelco, $60 \mathrm{~m} \times 0.25 \mathrm{~mm} \times 0.25 \mu \mathrm{m})$. The following temperature program was set for the column: $50^{\circ} \mathrm{C}$ (hold for $2 \mathrm{~min}$ ), and $5^{\circ} \mathrm{C} / \mathrm{min}$ up to $330^{\circ} \mathrm{C}$ (hold for $12 \mathrm{~min}$ ). The injector and linker temperatures were $335^{\circ} \mathrm{C}$ and $330^{\circ} \mathrm{C}$, respectively. The total separation time was 70 min. Linear velocity of carrier gas (helium 5.0) was $25 \mathrm{~cm} / \mathrm{min}$. The $1 \mu \mathrm{L}$ samples were dosed automatically by means of Shimadzu AOCi-20 autoinjector using splitless mode with $1 \mathrm{~min}$ sampling time. PAH 
detection was conducted as selected ion monitoring (SIM) and the detector measured the intensity of 64 mass ions characteristic for individual aromatic hydrocarbons. PAH identification was carried out on the basis of retention times and mass spectra obtained for the analytical standards of the analysed compounds (Supelco EPA 525 PAH Mix A, cat. \#48953-U), while quantitative analysis was conducted on the basis of calibration curves determined for individual polycyclic aromatic hydrocarbons $(0.5-50 \mu \mathrm{g} / \mathrm{mL})$. GCMS-Solution Ver.1.2 software (Shimadzu Corporation, Japan), which was used for the analysis of obtained chromatographic data.

\section{Analysis of Oil Derivatives Content in Soil}

The content of oil derivatives in soil was determined using the gravimetric method. Erlenmeyer flasks of $300 \mathrm{~mL}$ were dried in a thermostat at $105^{\circ} \mathrm{C}$ and then cooled for $1 \mathrm{~h}$ in a desiccator. Afterward, the flasks were weighed on an analytic balance with accuracy to $1 \cdot 10^{-5} \mathrm{~g}$. The extraction was carried out using light petroleum (petroleum benzine boiling range 40-60; Sigma-Aldrich, Cat. \#: 32299) in Soxhlet apparatus of $150 \mathrm{~mL}$. When the weighing was complete the flasks were coupled with Soxhlet apparatus and reflux condensers. Extraction thimbles containing previously prepared soil samples (c.a. 10-11 g of soil treated with $18 \%$ hydrochloric acid and then dried in the presence of calcinated anhydrous magnesium sulphate) were transferred to Soxhlet apparatuses. The extraction involving multiple rinsing of a soil sample with organic solvent was conducted at $70-80^{\circ} \mathrm{C}$ for $6 \mathrm{~h}$. After the extraction ended, the samples were condensed until the post-extraction residue formed on the bottom of Erlenmeyer flasks. Subsequently, the flasks were transferred to a thermostat and warmed at $105^{\circ} \mathrm{C}$ for $1.5 \mathrm{~h}$ in order to dry the post-extraction remains of light petroleum residue. After that time the flasks were removed to the desiccator and cooled for $1 \mathrm{~h}$ and then weighed on an analytical balance. On the basis of obtained results and determined soil dry mass, the content of hydrocarbon compounds was assessed in $1 \mathrm{~kg}$ of soil d. m.

The crucibles designed for dry mass assessment were dried for c.a. $12 \mathrm{~h}$ at $105^{\circ} \mathrm{C}$. On the day the assessments were made, dried crucibles were transferred to the desiccator, in which they were cooled for $1 \mathrm{~h}$. Subsequently, the crucibles were weighed on an electronic balance with accuracy to $1 \cdot 10^{-3} \mathrm{~g}$. The soil-dosed c.a. $10 \mathrm{~g}$ was transferred to the weighed crucibles, which were again weighed. Next, the crucibles were put in the thermostat for $5 \mathrm{~h}\left(105^{\circ} \mathrm{C}\right)$. Afterward, the crucibles were cooled in the desiccator for $1 \mathrm{~h}$, then weighed and percentage dry mass content was determined. The assessments were made in two independent replications and the obtained final result is their average value.
Statistical computations were made using the Statistica 13.1 PL computer programme. ANOVA twoway analysis was carried out. Means were diversified using NIR Fisher test at significance level $\alpha=0.05$.

\section{Results and Discussion}

No significant decrease in survival rate of $H$. rufipes beetles were observed during the rearing, either under conditions of unpolluted soil or soil polluted with petrol (Fig. 1a). Starting from the $3^{\text {rd }}$ week of rearing,
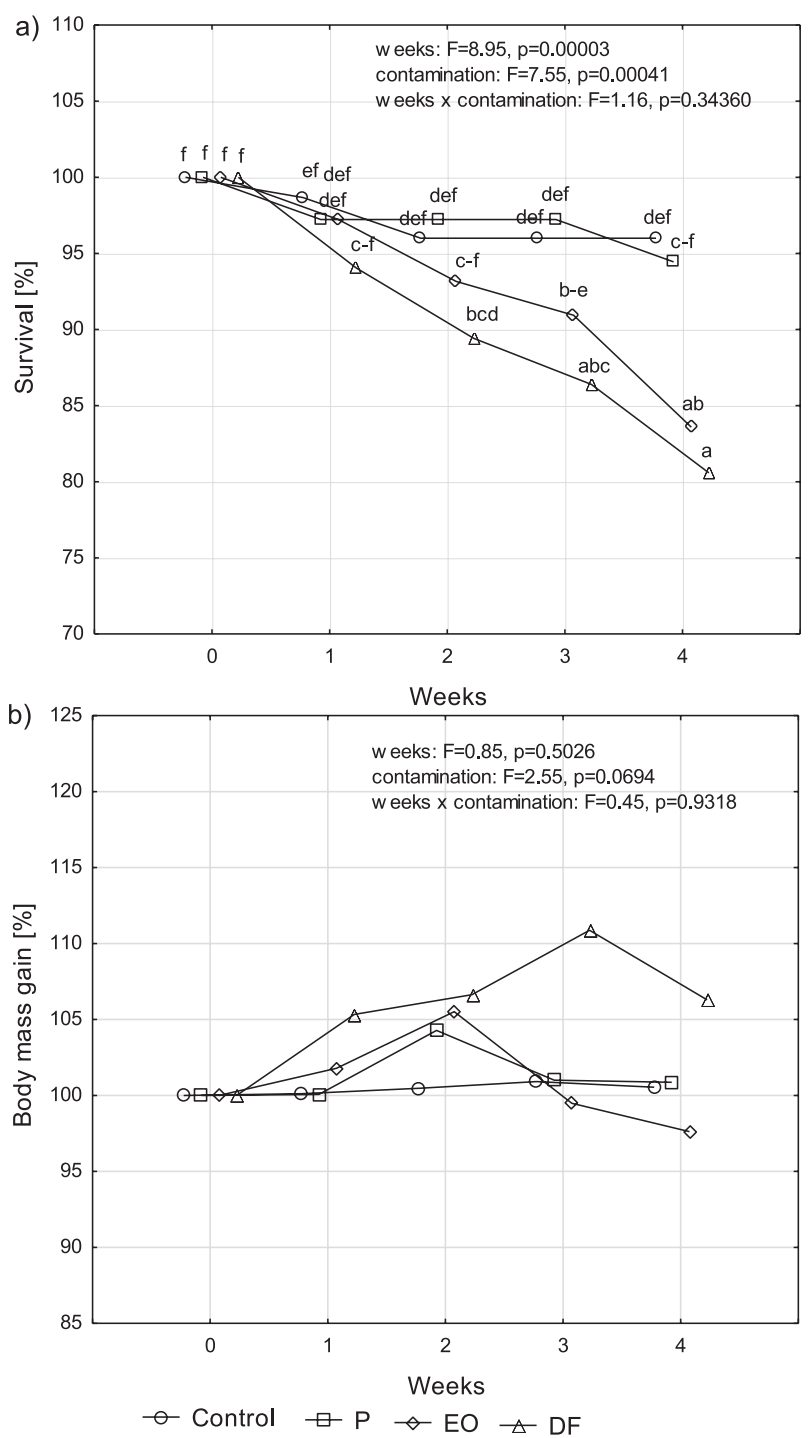

Fig. 1. Survival a) of Harpalus rufipes Deg. (\%; $100 \%$ equals 63 animals provided at the beginning of the experiment in each experimental group) and body mass gain $\mathrm{b}$ ) of a single individual of $H$. rufipes $(\% ; 100 \%$ equals the body mass at the beginning of the experiment in each experimental group) reared in soil contaminated with petroleum products: unleaded petrol $(\mathrm{P})$, used engine oil (EO) and diesel oil (DF) during four weeks of experiment; means marked with the same letters do not differ significantly according to NIR test at $\alpha=0.05$; factors: weeks $\mathrm{x}$ contamination, and the means presented in Fig. 1b) do not differ significantly. 


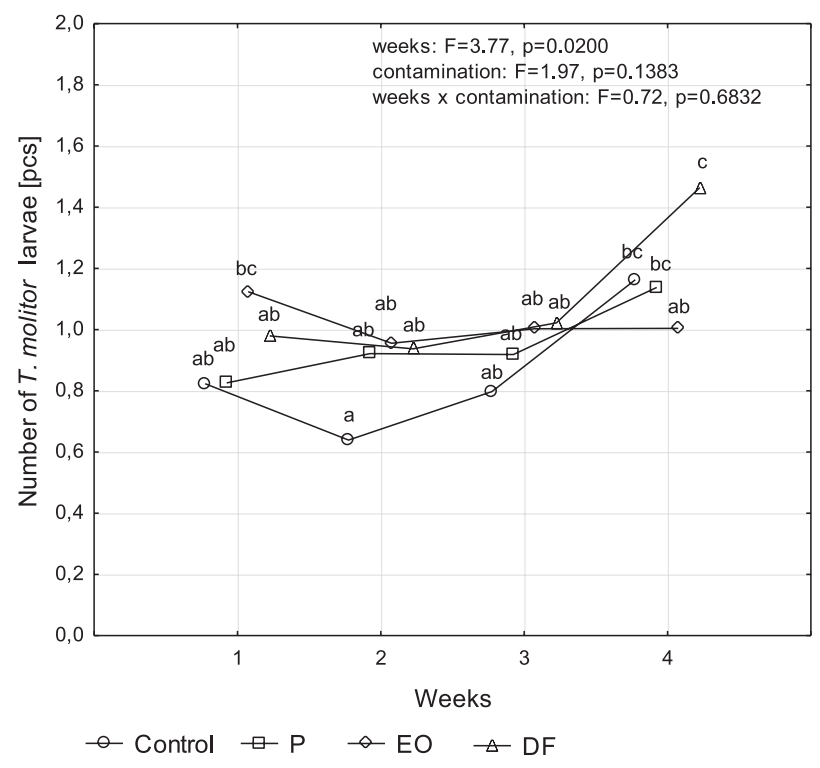

Fig. 2. Number of T. molitor larvae killed by one Harpalus rufipes Deg. reared in soil contaminated with petroleum products: unleaded petrol (P), used engine oil (EO) and diesel oil (DF) during four weeks of experiment; means marked with the same letters do not differ significantly according to NIR test at $\alpha=0.05$; factors: weeks $\mathrm{x}$ contamination.

a significantly lower survival rate characterized beetles cultured in the presence of soil contaminated with used engine oil. About $10 \%$ of the specimens died at that time, whereas after four weeks already about $16 \%$. Diesel oil affected beetle survival rate even more negatively.
Significant negative effect was discernible already after 2 weeks of rearing (lethality on the level of $10 \%$ ). In the $3^{\text {rd }}$ and $4^{\text {th }}$ weeks, respectively, about 14 and $19 \% \quad H$. rufipes beetles died. In the experiment conducted the previous year similar results were noted two months after oil derivatives were poured on the soil [25]. In the same experiment from among the analysed substances, diesel fuel most negatively also affected beetle survival rate (only 25 out of 36 specimens survived after 4 weeks of rearing). Lighter mixtures of oil derivatives were generally associated with lower ranges of toxic effects than heavier crude oil [26]. Still, in invertebrates the effect depends not only on the amount or composition of the mixture, but also on the species. A diversification in Drosophila melanogaster development exposed to benzene, toluene or xylene was demonstrated depending on a single or in mixture application of these substances [27]. Exceptional toxicity of diesel oil for invertebrates was also evidenced in other experiments [28-30]. The presence of this pollutant caused f. ex. incapacity to procreate in collembola regardless of the dose applied in the soil (5, 50 and $100 \mathrm{ml} / \mathrm{kg}$ of soil) [30]. Oil derivatives' effect on survival rate and growth of invertebrates is usually connected with the method of their feeding. Research conducted by Lee et al. [31] revealed that, concerning the above-mentioned parameters, Viviparus georgianus snail proved to be more sensitive than Pseudosuccinea columella, the first being a detrivore assimilating contaminants from the sediments, while $P$. columella is a herbivore that does not directly assimilate contaminants. Therefore, H. rufipes beetles

Table 1. Concentrations of selected PAHs in bodies of Harpalus rufipes Deg. ( $\mu \mathrm{g} / \mathrm{g}$ of animal material) during exposure to various hydrocarbon compounds: 2 - after 2 weeks of experiment, 4 - after 4 weeks of experiment, P - soil contaminated with petrol, DF - soil contaminated with diesel fuel, EO - soil contaminated with engine oil; nd - not detected; presented results are average values of two independent repetitions with the calculated standard deviation.

\begin{tabular}{|c|c|c|c|c|c|c|}
\hline & \multicolumn{2}{|c|}{ Petrol } & \multicolumn{2}{|c|}{ Diesel Fuel } & \multicolumn{2}{|c|}{ Engine Oil } \\
\hline & 2 & 4 & 2 & 4 & 2 & 4 \\
\hline Acenaphthylene & nd & $0.32 \pm 0.06^{\mathrm{b}^{*}}$ & $0.29 \pm 0.03^{\mathrm{b}}$ & $0.11 \pm 0.04^{\mathrm{a}}$ & nd & $0.01 \pm 0.003^{\mathrm{a}}$ \\
\hline Fluorene & $0.15 \pm 0.01^{\mathrm{c}}$ & $0.10 \pm 0.02^{\mathrm{b}}$ & $0.01 \pm 0.005^{\mathrm{a}}$ & $0.02 \pm 0.007^{\mathrm{a}}$ & nd & nd \\
\hline Phenanthrene & $0.13 \pm 0.01^{\mathrm{bc}}$ & $0.06 \pm 0.01^{\mathrm{a}}$ & $0.20 \pm 0.03^{\mathrm{d}}$ & $0.09 \pm 0.02^{\mathrm{ab}}$ & $0.07 \pm 0.02^{\mathrm{ab}}$ & $0.15 \pm 0.05^{\mathrm{cd}}$ \\
\hline Anthracene & $0.24 \pm 0.04^{\mathrm{b}}$ & $0.51 \pm 0.05^{\mathrm{c}}$ & $0.14 \pm 0.02^{\mathrm{a}}$ & $0.15 \pm 0.02^{\mathrm{a}}$ & nd & $0.08 \pm 0.01^{\mathrm{a}}$ \\
\hline Pyrene & nd & nd & $1.55 \pm 0.31^{\mathrm{b}}$ & nd & $0.27 \pm 0.04^{\mathrm{a}}$ & nd \\
\hline Benz $[a]$ anthracene & nd & $0.08 \pm 0.01^{\mathrm{b}}$ & nd & $0.11 \pm 0.02^{\mathrm{c}}$ & $0.02 \pm 0.004^{\mathrm{a}}$ & $0.02 \pm 0.004^{\mathrm{a}}$ \\
\hline Chrysene & nd & $0.14 \pm 0.01^{\mathrm{b}}$ & nd & $0.03 \pm 0.01^{\mathrm{a}}$ & nd & $0.12 \pm 0.01^{\mathrm{b}}$ \\
\hline Benzo[b]fluoranthene & nd & $0.48 \pm 0.08^{b}$ & nd & nd & $0.26 \pm 0.06^{\mathrm{a}}$ & $0.68 \pm 0.14^{\mathrm{c}}$ \\
\hline Benzo[k]fluoranthene & nd & $0.08 \pm 0.01$ & nd & nd & nd & nd \\
\hline Benzo $[a]$ pyrene & $0.11 \pm 0.02^{\mathrm{a}}$ & $0.89 \pm 0.09^{\mathrm{b}}$ & nd & nd & nd & nd \\
\hline Dibenzo $[a . h]$ anthracene & nd & $0.14 \pm 0.02$ & nd & nd & nd & nd \\
\hline Benzo $[g h i]$ perylene & nd & $0.04 \pm 0.01$ & nd & nd & nd & nd \\
\hline
\end{tabular}

*Means in lines marked with the same letters do not differ significantly according to NIR test at $\alpha=0.05$. 
while feeding on T. molitor larvae were little susceptible to foodborne toxicity. However, they were often observed burrying themselves in the soil, which exposed them to contact with petroleum compounds through integuments. There is a considerable diversification in the response to oil derivatives depending on animal species and age [32, 33]. Considering their survival rate, adult earthworms are much more resistant to oil derivatives than their juvenile forms or Collembola. EC50 values expressed as a percentage of contaminated

a) 6000
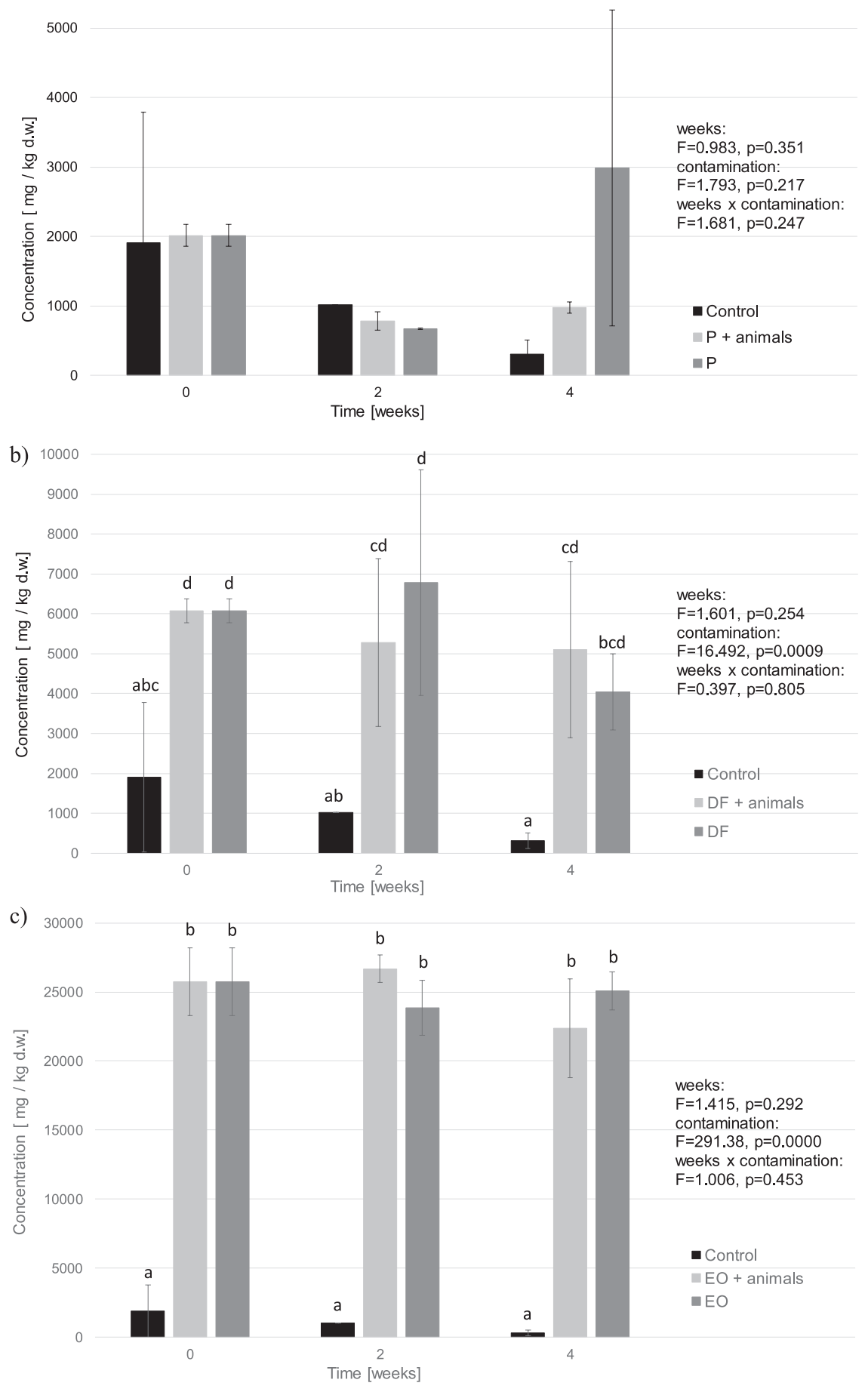

Fig. 3. Level of total petroleum hydrocarbons in soil contaminated with petrol a), diesel fuel b) and engine oil c). P + animals - petrol contaminated soil with animals; P - petrol contaminated soil without animals; DF + animals - diesel fuel contaminated soil with animals; DF - diesel fuel contaminated soil without animals; EO + animals - engine oil contaminated soil with animals; EO - engine oil contaminated soil without animals; Control - uncontaminated soil without Harpalus rufipes Deg. Presented results are average values of two independent repetitions with the calculated standard deviation. Means marked with the same letters do not differ significantly according to NIR test at $\alpha=0.05$. Factors: weeks $x$ contamination. The means presented on the figure a) do not differ significantly. 
soil in ISO soil test medium (weight per weight $-\mathrm{w} / \mathrm{w}$ ) for survival of Collembola in a 28 -day test was $11 \%$, for juvenile earthworms $-28 \%$ and for adult earthworms $74 \%$ [19]. This was also confirmed by the research of Wang et al. [34].

Beetles reared in conditions of control soil and soil contaminated with petrol and engine oil did not reveal any marked changes in their body mass during the rearing (Fig. 1b). A slight increase of body mass was observed in beetles cultured on the soil contaminated with diesel oil after 3 weeks of rearing, but still the difference in comparison to the control was statistically insignificant. Although in previous investigations these beetles were also characterized by a slightly bigger body mass by the end of a 4-week rearing on soil contaminated with diesel oil than at the beginning, the differences were not statistically proven [25]. It is possible that smaller specimens died first. However, this thesis is impossible to prove because during weekly weighing dead specimens were usually found bearing traces of gnawing by live specimens, so it was difficult to determine the precise body mass of dead specimens. The other explanation may be the activation of a defensive mechanism to eliminate the toxic effect of diesel fuel associated with the increased food requirement. Increases in average body mass of specimens exposed to diesel oil was correlated with the increase in average number of killed prey (Fig. 2). In the author's previous investigations diesel fuel doses of $3000 \mathrm{mg}$ of fuel / $\mathrm{kg}$ of soil stimulated an increase in isopoda body mass but did not affect their survival rate, which might confirm the second hypothesis [35]. Generally it is thought that body mass changes are not suitable biomarkers of petroleum product contamination [25].

The average number of Tenebrio molitor larvae killed by a single $H$. rufipes beetle was increasing in conditions of diesel fuel-contaminated soils, whereas it did not change under the influence of soil contamination with petrol and engine oil (Fig. 2). However, it should be mentioned that not all killed prey were consumed.

Results of the analysis of polycyclic aromatic hydrocarbon content in animal material samples were compiled in Table 1. In the case of petrol-contaminated soil the highest PAH values were registered in the $4^{\text {th }}$ week of the experiment. Simultaneously, increases in anthracene content from 0.24 in the second week to $0.51 \mu \mathrm{g}$ xenobiotic / $\mathrm{g}$ sample wet mass in the fourth week were registered. A similar increase was observed for benzo[a]pyrene (in concentrations of 0.11 and $0.89 \mu \mathrm{g} / \mathrm{g}$ wet mass), which may point to the accumulation of these compounds in $H$. rufipes bodies. The highest content of PAHs was noted for benzo[a]pyrene $-0.89 \mu \mathrm{g} / \mathrm{g}$ wet mass. Fig. 3a) shows a change in total hydrocarbons in soil samples treated with petrol. No increase in the efficiency of hydrocarbon degradation in the presence of $H$. rufipes was observed. In soil contaminated with diesel fuel, pyrene was the hydrocarbon of highest registered concentration, which after 2 weeks reached the level of $1.55 \mu \mathrm{g} / \mathrm{g}$ wet mass. However, its presence was not registered in the $4^{\text {th }}$ week of the test duration, which may evidence its detoxication by $H$. rufipes. Despite expected pyrene degradation, chromatographic analyses did not reveal its main intermediate compounds, i. e., 1-hydroxypyrene and its derivatives: pyrene-1-glucoside or pyrene-1-sulfate forming during this hydrocarbon biodegradation conducted by Porcellio scaber and Oniscus asselus [16]. Fig. 3b) presents the change in oil derivative concentrations in the soil contaminated with diesel fuel. No correlation between the depletion in total oil derivatives and the presence of analysed animals was observed in this variant. In soil polluted with engine oil, both in the $2^{\text {nd }}$ and $4^{\text {th }}$ week of the experiment we noted increased levels of benzo[b]fluoranthene $(0.26$ and $0.68 \mu \mathrm{g} / \mathrm{g}$ wet mass, respectively). The hydrocarbon level measured for the sample in the $4^{\text {th }}$ week of the experiment may indicate that this compound is not metabolized and accumulates in beetle organism. Fig. 3c) presents the change in total hydrocarbons in the soil treated with engine oil. No correlation was determined between $H$. rufipes presence and a change in total hydrocarbon content in the soil. It should be emphasized, however, that the rearing lasted only 1 month. For comparison, earthworms (organisms very effective in biopurification) need up to 12 weeks for biodegradation of TPH in soil contaminated with crude oil at $27.64 \%$ [36]. The observed tendencies to accumulate some PAHs may testify to the positive role of $H$. rufipes in the natural biodegradation of petroleumbased pollution. Especially that in the experiment we did not deal with dietary exposure, which is considered to be a major pathway for PAH accumulation [37].

\section{Conclusions}

1. Even within one year after the instance of contamination, Harpalus rufipes Deg. reveals sensitivity to the presence in its vicinity of engine oil and diesel fuel, visible as decreased survival rate. This indicates the high sensitivity of this species to the presence of oil derivatives in the soil and potential usefulness as a bioindicator of this type of pollution.

2. Petrol does not affect the beetle condition. All the analysed types of oil derivatives also did not negatively affect the beetle body mass gain and abilities to kill prey.

3. Short-term experiments did not reveal any dependence between the presence of the animals and efficiency of total hydrocarbon degradation.

4. Although possible degradation of pyrene was found, no intermediates formed during the biotransformation reaction of this hydrocarbon were identified.

5. A tendency for accumulation was observed for anthracene and benzo $[a]$ pyrene in conditions of soil polluted with petrol, and benzo $[b]$ fluoranthene 
in engine oil-polluted soil, which may indicate a significant contribution of $H$. rufipes in the natural biodegradation of oil derivatives.

\section{Acknowledgements}

Publication of this paper was financed by the Ministry of Science and Higher Education of the Republic of Poland and from the funds for science in 2009-2013 as a research project (N N305 151537).

\section{Conflict of Interest}

The authors declare no conflict of interest.

\section{References}

1. BIRTHISEL S.K., GALLANDT E.R., JABBOUR R. Habitat effects on second-order predation of the seed predator Harpalus rufipes and implications for weed seedbank management. Biol. Control 70, 65, 2014. doi:10.1016/j.biocontrol.2013.12.004.

2. EL-DANASOURY H., IGLESIAS-PINEIRO J. Predation by polyphagous carabid beetles on eggs of a pest slug: Potential implications of climate change. J. Appl. Entomol. 142, 340, 2018. doi:10.1111/jen.12474.

3. KEDZIOR R., SZWALEC A., MUNDALA P., SKALSKI T. Ground beetle assemblages in recultivated and spontaneously regenerated forest ecosystems on postindustrial areas. Sylwan 161, 512, 2017.

4. LABRUYERE S., PETIT S., RICCI B. Annual variation of oilseed rape habitat quality and role of grassy field margins for seed eating carabids in arable mosaics. Agric. For. Entomol. 20, 234, 2018. doi:10.1111/afe.12250.

5. LALONDE O., LEGERE A., STEVENSON F.C., ROY M., VANASSE A. Carabid beetle communities after 18 years of conservation tillage and crop rotation in a cool humid climate. Can. Entomol. 144, 645, 2012. doi:10.4039/ tce.2012.55.

6. SĄDEJ W., KOSEWSKA A., SĄDEJ W., NIETUPSKI M. Effects of fertilizer and land-use type on soil properties and ground beetle communities. B. Insectol. 65 (2), 239, 2012.

7. GOSPODAREK J. Effect of oil derivative spill on epigeal mezofauna. Proc. ECOpole 2 (2), 309, 2008.

8. TÓTHMÉRÉSZ B., MÁTHÉ I., BALÁZS E., MAGURA T. Responses of carabid beetles to urbanization in Transylvania (Romania). Landscape Urban Plan. 101, 330, 2011. DOI:10.1016/j.landurbplan.2011.02.038.

9. RESHETNIAK D.Y., PAKHOMOV O.Y., BRYGADYRENKO V.V. Possibility of identifying plant components of the diet of Harpalus rufipes (Coleoptera, Carabidae) by visual evaluation. Regulatory Mechanisms in Biosystems 8, 377, 2017. doi:10.15421/021758.

10. LEE M.S., ALBAJES R. Monitoring carabid indicators could reveal environmental impacts of genetically modified maize. Agric. For. Entomol. 18, 238, 2016. doi:10.1111/afe.12156.

11. IVSHINA I.B., KUYUKINA M.S., KRIVORUCHKO A.V., ELKIN A.A., MAKAROV S.O., CUNNINGHAM
C.J., PESHKUR T.A., ATLAS R.M., PHILP J.C. Oil spill problems and sustainable response strategies through new technologies. Environ. Sci-Proc. Imp. 17, 1201, 2015. doi:10.1039/c5em00070j.

12. GOSPODAREK J. Effect of soil pollution with oil derivatives on the occurrence of Harpalus rufipes Deg. (Coleoptera, Carabidae). Proceed. Ecopole, 8 (2), 385, 2014. DOI: $10.2429 /$ proc. $2014.8(2) 047$

13. KAMPE S., SCHLECHTRIEM C.. Bioaccumulation of hexachlorobenzene in the terrestrial isopod Porcellio scaber. Environ. Toxicol. Chem. 35 (11), 2867, 2016.

14. KOLAR L., JEMEC A, VAN GESTEL C,A, VALANT J., HRZENJAK R., ERZEN N.K., ZIDAR P. Toxicity of abamectin to the terrestrial isopod Porcellio scaber (Isopoda, Crustacea). Ecotoxicology 19 (5), 917, 2010.

15. BROERSE M., OORSPRONG H., VAN GESTEL CA. Cadmium affects toxicokinetics of pyrene in the collembolan Folsomia candida. Ecotoxicology 21 (3), 795, 2012.

16. STROOMBERG G.J., ARIESE F., VAN GESTEL C.A.M., VAN HATTUM N.H., VELTHORST N.H., VAN STRAALEN N.M. Pyrene biotransformation and kinetics in the hepatopancreas of the isopod Porcellio scaber. Arch. Environ. Contam. Toxicol. 47 (3), 324, 2004. DOI: $10.1007 /$ s00244-004-3097-y

17. KATAYAMA A. BHULA R.A., BURNS R.G., CARAZO E., FELSOT A., HAMILTON D., HARRIS C., Kim Y.H., KLETER G., KOEDEL W., LINDERS J., PEIJNENBURG W.G.M., SABLJIC A., STEPHENSON G.R., RACKE K.D., RUBIN B., TANAKA K., UNSWORTH J., WAUCHOPE D. Bioavailability of Xenobiotics in the Soil Environment. In: WHITACRE D. (eds) Reviews of Environmental Contamination and Toxicology. Reviews of Environmental Contamination and Toxicology (Continuation of Residue Reviews), 203. Springer, 2010, New York, NY

18. RODRIGUEZ-CAMPOS J., DENDOOVEN L., ALVAREZ- BERNAL D., CONTRERAS-RAMOS S.M. Potential of earthworms to accelerate removal of organic contaminants from soil: a review. Appl. Soil Ecol. 79, 10, 2014.

19. EOM I.C., RAST C., VEBER A.M., VASSEUR P. Ecotoxicity of polycyclic aromatic hydrocarbon (PAH) -contaminated soil. Ecotoxicol. Environ. Safe. 67, 190, 2007. DOI:10.1016/j.ecoenv.2006.12.020

20. GHAVIDEL A., RAD S.N., ALIKHANI H.A., YAKHCHALI B., POURBABAI A.A. Presence of Eisenia fetida enhanced phytoremediation of anthracene by Lolium perenne. Biosci. J. 34, 888, 2018.

21. DELORENZO M.E., KEY P.B., CHUNG K.W., PISARSKI E., SHADDRIX B., WIRTH E.F., PENNINGTON P.L., WADE J., FRANCO M., FULTON M.H. Comparative Toxicity of Two Chemical Dispersants and Dispersed Oil in Estuarine Organisms. Arch. Environ. Con. Tox. 74, 414, 2018. doi:10.1007/s00244-017-0430-9.

22. RUSIN M., GOSPODAREK J., NADGÓRSKA-SOCHA A. The effect of petroleum-derived substances on the growth and chemical composition of Vicia faba L. Pol. J. Environ. Stud. 24 (5), 2157, 2015.

23. LISTE H., FELGENTREU D. Crop growth, culturable bacteria and degradation of petrol hydrocarbons (PHCs) in a long-term contaminated field soil. Appl. Soil Ecol. 31, 43, 2006.

24. VAN GESTEL CA. Soil ecotoxicology: state of the art and future directions. Zookeys 176, 275, 2012. doi: 10.3897/ zookeys.176.2275. 
25. KAFEL A., GOSPODAREK J., ZAWISZA-RASZKA A., ROZPĘDEK K., SZULIŃSKA E. Effects of petroleum products polluted soil on ground beetle Harpalus rufipes. Ecol. Chem. Eng. A. 19 (7), 731, 2012. DOI: 10.2428/ ecea.2012.19(07)072.

26. EFROYMSON R.A., SAMPLE B.E., PETERSON M.J. Ecotoxicity Test Data for Total Petroleum Hydrocarbons in Soil: Plants and Soil - Dwelling Invertebrates. Hum. Ecol. Risk Asses. 10, 207, 2004. DOI: 10.1080/10807030490438175

27. SINGH M.P., RAM K.R., MISHRA M., SHRIVASTAVA M., SAXENA D.K., CHOWDHURI DK. Effects of co-exposure of benzene, toluene, and xylene to Drosophila melanogaster: Alteration in hsp70, hsp60, hsp83, hsp26, ROS generation and oxidative stress markers. Chemosphere, 79, 577, 2010. DOI: 10.1016/j. chemosphere.2010.01.054

28. GORCHAROENWAT P., PIYATIRATITIVORAKUL S., PENGPRECHA S. Effects of Temperature and Water Soluble Fraction of Palm Biodiesel and Diesel Fuel on Hatchability and Survival of First Stage Larvae of Macrobrachium rosenbergii. Environment Asia 8, 61, 2015.

29. SARDI A.E., RENAUD P.E., MORAIS G.C., MARTINS C.C., LANA P.C., CAMUS L. Effects of an in situ diesel oil spill on oxidative stress in the clam Anomalocardia flexuosa. Environ. Pollut. 230, 891, 2017. doi:10.1016/j. envpol.2017.07.040.

30. ANTONIOLLI Z.I., REDIN M., DE SOUZA E.L., POCOJESKI E. Heavy metal, pesticides and fuels: effect in the population of collembola in the soil. Ciencia Rural 43, 992, 2013.
31. LEE L.E.J., STASSEN J., MCDONALD A., CULSHAW C., VENOSA A.D., LEE K. Snails as biomonitors of oilspill and bioremediation strategies. Bioremediat. J. 6 (4), 373, 2002. DOI:10.1080/10889860290777675

32. RUSIN M., GOSPODAREK J., NADGÓRSKA-SOCHA A., BARCZYK G. Effect of petroleum-derived substances on life history traits of black bean aphid (Aphis fabae Scop.) and on the growth and chemical composition of broad bean. Ecotoxicology 26, 308, 2017.

33. GOSPODAREK J., PETRYSZAK P., KOLOCZEK H. The effect of the bioremediation of soil contaminated with petroleum derivatives on the occurrence of epigeic and edaphic fauna. Bioremediat. J. 20 (1), 38, 2016.

34. WANG S.J., YAN Z.G., LU G.G.L., WANG Q., LI F. Ecotoxicity assessment of aged petroleum sludge using a suite of effects-based end points in earthworm Eisenia fetida Environ. Monit. Assess. 169 (1-4), 417, 2010. DOI: 10.1007/s10661-009-1184-2

35. GOSPODAREK J. Survival rate of redworms and woodlice in soil contaminated with petrol, diesel oil and engine oil. Ecol. Chem. Eng. A 19 (11), 1369, 2012. DOI: 10.2428/ecea.2012.19(11)132

36. EKPERUSI O.A., AIGBODION F.I. Bioremediation of petroleum hydrocarbons from crude oil-contaminated soil with the earthworm: Hyperiodrilus africanus. Biotech 5, 957, 2015. doi:10.1007/s13205-015-0298-1.

37. ARIAS A.H., SOUISSI A., ROUSSIN M., OUDDANE B. SOUISSI S. Bioaccumulation of PAHs in marine zooplankton: an experimental study in the copepod Pseudodiaptomus marinus. Environ. Earth Sci. 75 (8), 2016. doi:10.1007/s12665-016-5472-1. 